Article

\title{
Recreationists' Perceptions of Scenic Beauty and Satisfaction at a Public Forest Managed for Endangered Wildlife
}

\author{
Ramesh Paudyal ${ }^{1}$ (D), Taylor V. Stein ${ }^{1, *}$, Holly K. Ober ${ }^{2}$, Marilyn E. Swisher ${ }^{3}$, Eric J. Jokela ${ }^{1}$ \\ and Damian C. Adams ${ }^{1}$ \\ 1 School of Forest Resources and Conservation, University of Florida, PO Box 110410, \\ Gainesville, FL 32611, USA; rpaudyal@ufl.edu (R.P.); ejokela@ufl.edu (E.J.J.); dcadams@ufl.edu (D.C.A.) \\ 2 North Florida Research and Education Center, University of Florida, 155 Research Road, \\ Quincy, FL 32351, USA; holly.ober@ufl.edu \\ 3 Department of Family, Youth \& Community Sciences, University of Florida, PO Box 110310, \\ Gainesville, FL 32611, USA; mesw@ufl.edu \\ * Correspondence: tstein@ufl.edu; Tel.: +1-352-846-0860
}

Received: 11 April 2018; Accepted: 29 April 2018; Published: 2 May 2018

\begin{abstract}
Prescribed burning and other active forest management treatments have been proven essential for maintaining suitable habitat conditions for many wildlife species, including the federally endangered red-cockaded woodpecker (RCW). This study examines the perception of forest management treatments of recreation users participating in various activities (hunting, hiking/backpacking, camping, off-highway vehicle riding, and canoeing/kayaking) in terms of scenic beauty and recreation satisfaction. We used photographic images to capture various forest management treatments of different intensity levels and times after treatments, and assessed users' perception of scenic beauty and recreation satisfaction. Results indicated variation among users participating in different recreation activities, but that good quality RCW habitats offered both higher scenic beauty and higher recreation satisfaction than poor quality habitats for most activity user groups. Finally, recreation satisfaction was statistically equal to perceived scenic beauty from both good and poor-quality RCW habitats for most of the activity user groups, thus suggesting the importance of scenic beauty of forest sites in determining recreation users' attainment of visit satisfaction. Findings conclude that forest sites developed as good quality RCW habitats in the present state also offer quality experience to recreation users, thus supporting multi-objective forestry practices in public forests.
\end{abstract}

Keywords: forest beauty; outdoor recreation; graphic elicitation technique; controlled burning; red-cockaded woodpecker; Ocala National Forest

\section{Introduction}

The red-cockaded woodpecker (Leuconotopicus borealis Vieillot) is a federally designated endangered keystone species of bird in the United States. This bird has a high ecological value as at least 27 species of vertebrates have been documented to use red-cockaded woodpecker (RCW) cavities either for roosting or nesting [1]. Even though the species is protected under the Endangered Species Act of 1973, managers face challenges to increase its abundance to levels high enough for recovery to occur. The primary threat to RCW is the lack of suitable habitats [1]. RCWs are territorial cooperative breeders that live in family groups, called clusters [2]. The birds require old pines, mostly of the age of 60 to 80 years, for cavity excavation and a basal area of about $9.2 \mathrm{~m}^{2} /$ ha with minimum midstory for the cluster $[3,4]$, and can only tolerate less than $2.3 \mathrm{~m}^{2} /$ ha of the hardwood overstory 
within the cluster [3]. Also, the foraging habitat requires an open structure with an intermediate density of pine, minimum or absent hardwood midstory, and abundant diverse herbaceous groundcovers [5]. Frequent, low intensity fires perpetuated these conditions historically [6,7]. Some researchers have found that the public perception of the scenic beauty of pine forest increases with increases in the size of trees and decreases with the presence of downed wood and groupings of trees [8-10]. It is likely that visitors see RCW habitats as scenically acceptable for recreational use because RCWs require large, mature trees for habitats critical to its survival.

Prescribed burning and tree harvesting play important roles in maintaining suitable habitat conditions for RCWs [11]. These forest management treatments are effective in maintaining ecologically healthy ecosystems and habitats for not only RCW, but also for many other wildlife species dependent on southern pine forests, including the gopher tortoise (Gopherus Polyphemus Daudin). Research related to the public perception of landscape aesthetics, however, has shown that people do not always perceive ecologically healthy ecosystems as aesthetically pleasing and acceptable [12-16]. These findings suggest that southern pine forests that have undergone recent prescribed burning could be relatively unattractive to recreation users. However, public perception research has also found that the perceived scenic beauty of forest sites is much higher a few years after burning than at the pre-fire level [17]. Our research builds on these findings by examining how different user groups visiting a site for specific recreational purposes perceive scenic beauty. Our research focuses specifically on how recreation users perceive scenic beauty and recreation satisfaction from forest sites maintained as RCW habitats that have undergone prescribed burning.

Further, the recovery of RCW populations requires accommodation through the expansion of suitable habitat conditions. Although these birds were once distributed nearly continuously throughout the southeastern US, they are now present in distinct populations isolated by vast gaps of unoccupied acreage [18]. Foresters use various management treatments to develop a forest site into a suitable habitat for RCWs, which is a lengthy process. These treatments may include even- and multi-age management systems to facilitate regeneration, thinning to reduce stand density and to allow growth of the remaining trees, and prescribed burning to suppress the hardwood midstory. Forest sites near and around currently suitable RCW habitats can be in various developmental stages leading to suitable RCW habitats. However, the public may not always be aware of the objectives of these forest management treatments and it is important to understand how recreation users react to them in public forests. This study examines how different recreation activity users perceive scenic beauty and recreation satisfaction from forest sites that offer good quality RCW conditions in the present state, and forest sites that are not yet developed as good quality habitats. Specifically, this study examines the following research questions.

- How do recreation users who participate in different nature-based recreation activities perceive scenic beauty and recreation satisfaction from public forests?

- Do good quality RCW habitat conditions offer higher scenic beauty and recreation satisfaction to recreation users than poor quality RCW habitat conditions?

- Do forest sites perceived to have higher scenic beauty also offer higher recreation satisfaction to users?

\section{Scenic Beauty and Recreation Satisfaction}

The landscape perception literature has used the terms "scenic beauty", "landscape quality", "visual quality", "scenic quality", or "natural beauty" to refer to the aesthetic component of the environment. However, Daniel and Boster [19] and Daniel and Vining [20] argued that "scenic beauty" best captures the meaning associated with visual appreciation of the forest environment. Daniel defines scenic beauty as "visual aesthetic quality" [21]. The terms "scenic beauty" and "scenic value" have been used interchangeably in the literature even though Johnson, et al. [22] operationalized these terms as two conceptually separate constructs. Others have suggested that the relationship between these two constructs is not entirely clear because the construct "scenic value" gives different meanings 
in different contexts (economics and psychological). In this study, the term "scenic beauty" refers to Daniel's [21] definition of scenic beauty for forest aesthetic assessment.

In a recreation context, expectancy valence theory suggests that people participate in outdoor recreation to fulfil preferred needs, motivations, or expected experiences $[23,24]$. The congruence between aspirations and the perceived reality of experiences is defined as recreation satisfaction in this theoretical perspective [25]. In this research context, recreation satisfaction is operationalized as the congruence between desired experience and perceived attainment of experience associated with the appearance of recreation sites [26].

Although the scenic beauty of a forest site could consistently contribute to recreation satisfaction and the desire to visit an area [27], scenic beauty may not be the most important factor in all cases. For example, Tahvanainen et al. [28] examined perceived scenic beauty and recreation preference of five forest management practices: small clear cutting, thinning, removal of undergrowth, natural state, and traditionally managed cultural landscape. The results showed no clear association between scenic beauty and recreation preference. Likewise, Brunson and Shelby [29] examined the scenic beauty and acceptability of various forest management practices and found that the acceptability rating of each forest management practice was higher when the setting was considered as a place to hike compared to when it was considered as a place to camp [29]. The authors suggested that users' perceptions of hiking quality were influenced by site attributes, such as the presence of hiking only on trails, whereas perceptions of camping quality were more influenced by offsite attributes, such as the distance to water bodies or other recreation attractions. This finding implies that recreation users' preferences of site and stand characteristics depend upon the activity in which they are participating [29]. In addition, research has shown that the more a recreation activity is connected to the natural resources on a site, the more the user is concerned about environmental issues associated with those resources [30]. For example, kayakers are more likely to be concerned about river pollution than about other environmental issues that do not directly affect their experience [30]. Based on these findings, one could hypothesize that appreciative activity users like hikers who view the scenery at close range could be more concerned about forest scenery than motorized recreationists like OHV (off-highway vehicle) users and consumptive recreationists like hunters, who may depend less on the aesthetic attributes of the forest for satisfaction. Thus, different recreation users may perceive the recreation quality of forest management practices in wildlife habitats differently.

Studies have shown that the physical characteristics of forest attributes such as tree density and forest type account for a significant proportion of the variance in the public perception of scenic beauty [21]. However, different cultural and social traits of the observers have also been found to affect the evaluation of scenic beauty and recreation quality of forests $[19,31]$. The psychophysical approach to landscape scenic beauty evaluation emphasizes the use of mathematical modeling (scenic beauty estimation (SBE) model) to examine relationships between objectively quantifiable site attributes and subjective ratings of the site [19]. One of the strengths of this approach is that it can relate changes in manipulative site characteristics with their impacts on scenic beauty [32]. However, a major criticism of the psychophysical model is its limited ability to produce theoretical explanations of predictor variables. Specifically, it places little focus on psychological processes that mediate the relationship between physical attributes and aesthetic ratings of a site [32]. In addition, the SBE model does not account for the potential variation in scenic beauty perception across publics of different socio-cultural, cognitive, and experiential characteristics. Other researchers have suggested that forest and landscape preference is a function of both the scene characteristics (forest attributes and silvicultural treatments) and human characteristics [33,34]. Therefore, it is important to examine the variation in perceived scenic beauty and recreation preferences across recreationists of different experiential, cognitive, and socio-cultural characteristics.

The cognitive and experiential paradigm involves assessment of forest scenic beauty by human observers taking into account the socio-cultural factors, human-forest interactions, human meanings associated with the forest, experience, and expectations [35,36]. The concept of human interaction 
with nature refers to what people put into and take away from nature. For example, whether visitors hike or view the scenery will significantly affect the nature-person interaction and, in turn, the user's perception of the aesthetic quality of the site [35]. Hull and Reveli [36] argue that a person's immediate purpose in an environment influences the type of information sought and the criteria used to evaluate that environment. They suggest that landscape preferences are learned and depend upon a person's culture, past experiences, and current purposes. Based on this concept, various researchers have examined the role of socio-cultural and experiential factors on the perception of scenic beauty and recreation preferences. Nonetheless, there is inconsistency in the literature regarding the effect of experiential and socio-cultural factors on the perception of scenic beauty and recreation quality of forest sites.

Some researchers have found similarities in scenic beauty evaluations of landscapes among persons of different ages, genders, professions, socio-economic status, and cultures $[19,20,33,37,38]$. In contrast, other studies have found significant variations in perception/attitude about scenic beauty and recreation quality across observers of different age groups, genders, and residential settings. For example, one recent study [28] found that middle-aged and older respondents perceived the clearcutting method of reproduction as increasing scenic beauty, whereas younger respondents thought it would decrease scenic beauty. In the same study, rural residents thought that this method of reproduction would have a negative impact on scenic beauty, while urban residents thought it would improve scenic beauty [28]. Similarly, a national survey of public perception and acceptance of prescribed fire [39] showed that African American and Hispanics were significantly more concerned about the impact of prescribed fire on aesthetics and harm to wildlife than Caucasians. Likewise, visitors with a greater number of previous visits to a site were found to prefer areas that fit more primitive recreation opportunity spectrum (ROS) classes than visitors with fewer previous visits [40]. This implies that frequent visitors could avoid sites that exhibit a higher proportion of visible human disturbances like prescribed burning. It is also possible that visitors who visit a site more frequently are more aware of forest management objectives for that site and have different standards of acceptance than less frequent visitors. However, none of the previous studies on forest aesthetic perception focused on management practices specific to habitat management for endangered wildlife species like the RCW. This scenario is highly relevant because managers of federal lands are mandated to manage in such a way that the habitat is enhanced for federally endangered species, and thus the principals of improving conditions for these species guide the management of large acreages of public lands. Examination of perceived scenic beauty and recreation satisfaction across various activity users who have different purposes for their recreation visits remains a little-researched topic. As a result, it is important to know how the purposes of recreational visits (participation in different recreation activities) are related to the perception of scenic beauty and recreation satisfaction from forest sites maintained as RCW habitats.

This study follows the cognitive and experiential paradigm of landscape aesthetic perception, borrowing methodological techniques from the psychophysical paradigm, to examine how the recreation activity people choose and quality of the RCW habitat affect users' perceptions of scenic beauty and recreation satisfaction. Specifically, the following hypotheses were tested.

Hypothesis 1 (H1). Recreation users who participate in different nature-based recreation activities have different levels of perceived scenic beauty and recreation satisfaction.

Hypothesis 2 (H2). Good quality RCW habitat offers higher scenic beauty and recreation satisfaction to recreation users than a poor-quality $R C W$ habitat.

Hypothesis 3 (H3). Forest sites perceived to have higher scenic beauty also offer higher recreation satisfaction and vice versa in both good quality habitats and poor-quality habitats. 


\section{Materials and Methods}

\subsection{Research Design and Survey Instrument}

The target population of interest in this study included outdoor recreation users of managed public natural areas in Florida. The accessible or study population was adult outdoor recreation users of Ocala National Forest (ONF), a $1570 \mathrm{~km}^{2}$ property located in central Florida, USA. Onsite data collections were made from recreationists 18 years or older that were encountered at trailheads or in parking lots of various recreation areas in ONF from April 2016 to February 2017. If the party included two or more people, the individual with the most recent birthday was invited to complete the questionnaire and index [41]. Among the 242 recreation users approached onsite, 209 agreed to take the survey, which was a response rate of $86.0 \%$.

Assessing recreation users' immediate perception of scenic beauty and recreation satisfaction as influenced by various management conditions, like prescribed burning of forest sites, poses challenges, including the added cost and time required for onsite data collection. Users engaged in recreation can also be reluctant to take time away from the recreational experience to participate in research. We chose to conduct onsite research in order to understand how the immediate recreational experience affects perceptions of scenic beauty. To reduce burdens on both the researcher and respondents, we presented respondents with pictures. Presenting respondents with photographs exposes people to various site conditions in less time than onsite physical observation of different habitats and minimizes the logistical burden of transporting people to sites [19,29]. Most past studies used photographs to assess the scenic beauty of forest sites from college students or the public in an indoor setting, assuming that people's perception of scenic quality is mostly determined by visual inputs [42]. However, those studies did not capture the potential effect of onsite experience on the perception of scenic beauty and recreation satisfaction of various forest conditions. This research also used photographs, but assessment of scenic beauty and recreation satisfaction were obtained from onsite recreation users.

Pictures used to represent good and poor-quality habitats were selected by an expert panel in a two-stage process. Initially, 12 pictures (Figure S1) taken from various forest sites in the ONF using a digital single-lens reflex camera were selected. The pictures represented typical RCW habitats and surrounding areas with diverse tree sizes, densities, and ground cover at various times after prescribed burning and other management treatments employed, such as regeneration cutting. The same settings and brightness (1/250 s f/8 $35 \mathrm{~mm}$, auto ISO, flash off) were used for all pictures to minimize the effect of camera settings on the visual quality of pictures. A photobook with randomly ordered one color picture (10.5 inch by 7.25 inch) per page, printed on copy paper and laminated with a three Mil thickness plastic sleeve, was prepared for respondents' assessment of scenic beauty and recreation satisfaction. A common problem in response bias is that ordered or grouped items tend to cause people to keep making the same selection among responses [43]. Random presentation of pictures was designed to prevent this common problem. After the questionnaires were completed, a panel of six experts in silviculture and wildlife habitats in southern forests selected the four pictures that best represented good quality RCW habitat conditions and the four pictures that represented the poorest quality RCW habitat conditions in the current state. Three pictures from each category (total six) that produced the greatest consensus were selected for analyses (Figure 1). 


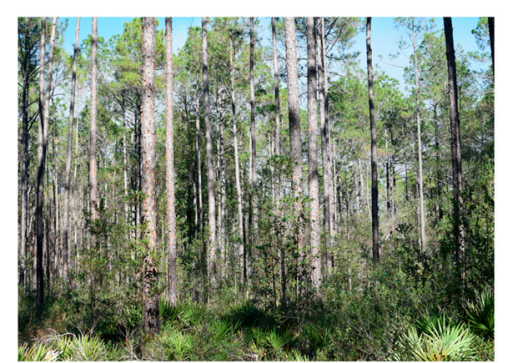

Picture 1. SB 7.2(2.3), RS 6.6(2.7)

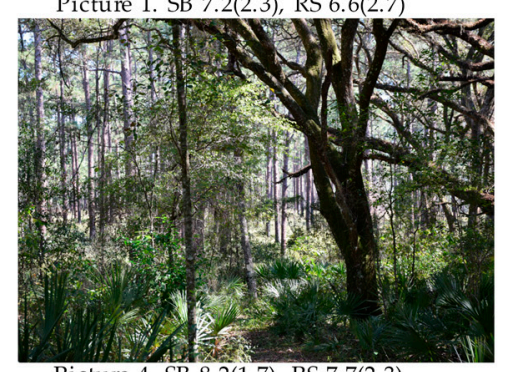

Picture 4. SB 8.2(1.7), RS 7.7(2.3)

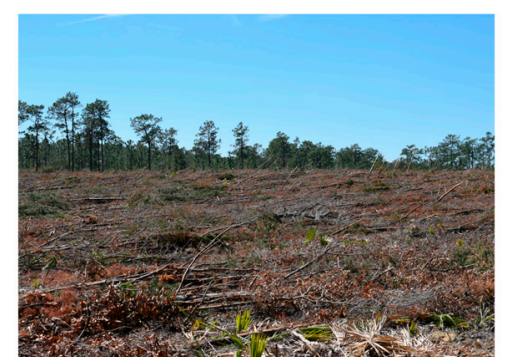

Picture 2. SB 3.1(2.6), RS 3.3(2.9)

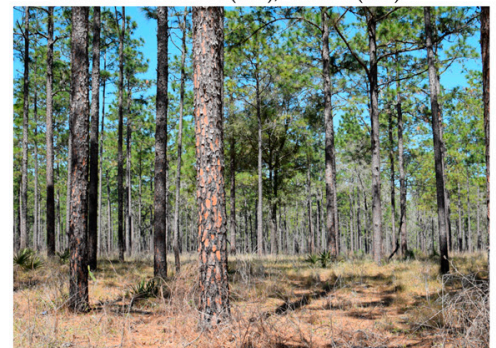

Picture 5. SB 7.3(2.2), RS 7.2(2.5)

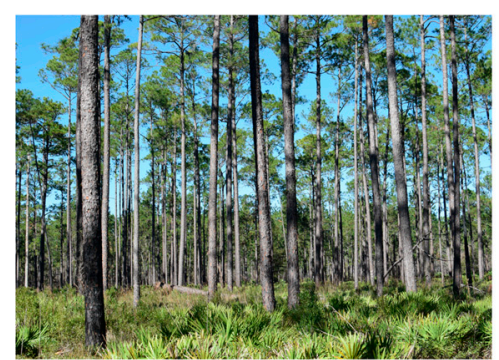

Picture 3. SB 7.6(2.1), RS 7.1(2.5)

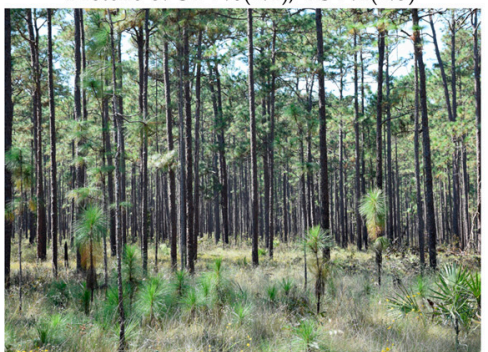

Picture 6. SB 7.7(2.2), RS 7.4(2.5)

Figure 1. Photographic images used for scenic beauty and recreation satisfaction ratings of adult outdoor recreation users in Ocala National Forest, USA. SB: scenic beauty, RS: recreation satisfaction, values in ( ) indicate standard deviation. Pictures 3, 5, and 6 represent a good red-cockaded woodpecker (RCW) habitat and pictures 1, 2, and 4 represent a poor RCW habitat in the current state, as voted by the panel of six silviculture and RCW habitat professionals.

A two-stage test of the questionnaire occurred prior to data collection. First, seven graduate and undergraduate students from forestry and natural resource programs at the University of Florida provided feedback regarding clarity of the questions, such as wording, ease of comprehension, and meaning of questions. After revising the questionnaire based on this test, the questionnaire was pilot tested with 42 recreation visitors at ONF.

\subsection{Measurement and Analysis}

Grouping respondents by recreation activity was crucial to comparing the perception of scenic beauty and recreation satisfaction among activity user groups. However, almost all respondents reported participating in more than one activity. Thus, respondents were asked to list, in order of importance, the three major activities they participated in during the day they were interviewed. Then, respondents were divided into groups based on their primary (first listed) activity. Respondents were asked to rate scenic beauty and their likely attainment of recreation satisfaction if they had to recreate on forest sites where the surrounding view corresponded to that depicted in each picture. To minimize potential response bias associated with trends in picture order, the 12 selected pictures were placed in the photobook randomly and the same photobook was used for all respondents. Figure 1 shows the pictures in the same order they were presented to the respondents. The scenic beauty rating scale ranged from 1 (not at all scenic) to 10 (very scenic) and the recreation satisfaction rating scale ranged from 1 (not at all satisfied) to 10 (very satisfied).

SPSS 24.0 statistical software (IBM, Armonk, NY, USA) was used to analyze the data. Item total correlation and Cronbach's alpha coefficient were used to assess the reliability of index scores. Cronbach's alpha values for both scenic beauty and recreation satisfaction indices were $\geq 0.70$ for both sets of pictures, those representing good and poor RCW habitats. Likewise, item total correlation of each picture from each habitat quality was $\geq 0.40$ for both scenic beauty and recreation satisfaction, suggesting that the scores were reliable. Analysis of variance or an equivalent Welch test (for unequal variance) were used to compare the perception of scenic beauty and recreation satisfaction among activity user groups (H1). Tukey's Post Hoc test or Dunnett's C test (for unequal variances) were used 
for the multiple comparison test. A paired sample t-test was used to compare good quality RCW habitats and poor-quality RCW habitats in terms of both scenic beauty and recreation satisfaction (H2) and for differences between scenic beauty and recreation satisfaction for each RCW habitat quality $(\mathrm{H} 3)$ for each recreation activity user group. For all tests, $\eta^{2}$ was used to measure the effect size. According to Cohen [44], the effect size should be interpreted as small $\left(\eta^{2}=0.01\right)$, medium $\left(\eta^{2}=0.06\right)$, and large $\left(\eta^{2}=0.14\right)$.

\section{Results}

\subsection{Descriptive Characteristics of Sample}

The primary activity reported by respondents $(n=209)$ was hiking or backpacking $(30 \%)$, off-highway vehicle (OHV) riding (16\%), camping (18\%), hunting $(12 \%)$, and canoeing or kayaking $(24 \%)$. The average age of the respondents was 42 (Std. Dev. $=14$ ) years, with $30 \%$ of the respondents $\leq 30$ years old and $14 \% \geq 60$ years old. The proportion of male respondents $(71 \%)$ was much higher than female respondents (31\%). About half of the respondents $(47 \%)$ had an education level of college degree or higher, whereas $20 \%$ had education attainment of high school or below. About $60 \%$ of the respondents were fulltime employed, $14 \%$ were retired, and about $10 \%$ each were self-employed and students. In terms of race and ethnicity, almost all respondents reported their race as White $(96 \%)$ and $8 \%$ of the respondents reported their ethnicity as Spanish, Hispanic, or Latino. One-third of the respondents had an annual household income $<\$ 50,000$ US dollars, whereas one quarter of respondents had an annual income $\geq \$ 100,000$ US dollars.

\subsection{RCW Habitat Quality and Perception of Scenic Beauty and Recreation Satisfaction}

Among the six photographic images (Figure 1), a forest site with mixed pine and hardwood trees (Picture 4) received the highest rating for both scenic beauty and recreation satisfaction, whereas a recently regenerated stand received the lowest rating for both (Picture 2). In general, respondents rated both scenic beauty and recreation satisfaction higher for forest sites that had mixed species of trees, mature and thinned trees with a large depth of view, no recent evidence of burning, sites with lush palmetto, and evidence of regeneration. On the other hand, forest sites with immature and dense trees and recent burning scored lower for both scenic beauty and recreation satisfaction.

Scenic beauty and recreation satisfaction index scores differed among recreation activity user groups (Table 1) $(p<0.05)$ for both good and poor-quality RCW habitats, with a larger effect size for the poor-quality habitat relative to the good-quality habitat. The good-quality RCW habitat was perceived similarly by hunters and OHV users in terms of scenic beauty and similarly by hunters, $\mathrm{OHV}$ users, and hikers/backpackers in terms of recreation satisfaction. In contrast, hunters rated both scenic beauty and recreation satisfaction for the poor-quality RCW habitat significantly higher than all other recreation activity user groups $(p<0.05)$. Campers and canoers/kayakers generally scored all conditions low and rated scenic beauty and recreation satisfaction of both good and poor-quality RCW habitats lowest $(p<0.05)$. Hikers/backpackers rated the scenic beauty of both good and poor-quality RCW habitats as low, as did campers and canoers/kayakers, but their ratings of recreation satisfaction from both habitats were as high as those of OHV users.

Comparisons between the good and poor-quality RCW habitat within each recreation activity user group (Table 2) indicates that the good-quality RCW habitat offers higher scenic beauty and recreation satisfaction to recreation users than the poor-quality RCW habitat. All recreation activity user groups except hunters scored both scenic beauty and recreation satisfaction higher for the good-quality habitat than for the poor-quality habitat $(p<0.05)$. Hunters also reported higher scenic beauty for the good-quality RCW habitat than the poor-quality habitat, but they were less discerning in that they reported attaining similar recreation satisfaction from both good and poor-quality habitats. 
Table 1. Comparison among recreation activity user groups in terms of perceived scenic beauty and recreation satisfaction of good and poor-quality red-cockaded woodpecker habitats in Ocala National Forest, Florida, USA.

\begin{tabular}{cccccccc}
\hline & Average & $\begin{array}{c}\text { Hiking/ } \\
\text { Backpacking }\end{array}$ & $\begin{array}{c}\text { OHV } \\
\text { Riding }\end{array}$ & Camping & Hunting & $\begin{array}{c}\text { Canoeing/ } \\
\text { Kayaking }\end{array}$ & Effect Size \\
\hline Good quality habitat & 7.5 & $7.5^{\mathrm{a}}$ & $8.1^{\mathrm{b}}$ & $7.2^{\mathrm{a}}$ & $8.2^{\mathrm{b}}$ & $7.2^{\mathrm{a}}$ & 0.05 \\
$\quad \begin{array}{c}\text { Scenic beauty } \\
\text { Recreation satisfaction }\end{array}$ & 7.2 & $7.5^{\mathrm{a}}$ & $7.6^{\mathrm{a}}$ & $6.6^{\mathrm{b}}$ & $8.0^{\mathrm{a}}$ & $6.7^{\mathrm{b}}$ & 0.05 \\
$\begin{array}{c}\text { Poor quality habitat } \\
\quad \text { Scenic beauty }\end{array}$ & 6.1 & $5.8^{\mathrm{a}}$ & $6.7^{\mathrm{b}}$ & $6.0^{\mathrm{a}}$ & $7.4^{\mathrm{c}}$ & $5.6^{\mathrm{a}}$ & 0.12 \\
Recreation satisfaction & 5.8 & $5.8^{\mathrm{a}}$ & $6.2^{\mathrm{a}}$ & $5.2^{\mathrm{b}}$ & $7.5^{\mathrm{c}}$ & $5.3^{\mathrm{b}}$ & 0.12 \\
\hline
\end{tabular}

${ }^{a b c}$ Different letters indicate significance of group difference at $5 \%$ level. OHV: off-highway vehicle.

Table 2. Comparison between good and poor-quality red-cockaded woodpecker habitats in Ocala National Forest in terms of recreationists' perceived scenic beauty and recreation satisfaction.

\begin{tabular}{|c|c|c|c|c|c|c|c|c|}
\hline \multirow[b]{2}{*}{ Recreation Activities } & \multicolumn{4}{|c|}{ Scenic Beauty } & \multicolumn{4}{|c|}{ Recreation Satisfaction } \\
\hline & $\begin{array}{c}\text { Good } \\
\text { Habitat }\end{array}$ & $\begin{array}{c}\text { Poor } \\
\text { Habitat }\end{array}$ & Diff. & $\begin{array}{c}\text { Effect } \\
\text { Size }\end{array}$ & $\begin{array}{c}\text { Good } \\
\text { Habitat }\end{array}$ & $\begin{array}{c}\text { Poor } \\
\text { Habitat }\end{array}$ & Diff. & $\begin{array}{c}\text { Effect } \\
\text { Size }\end{array}$ \\
\hline Hiking/backpacking & 7.5 & 5.8 & $1.6^{* *}$ & 0.68 & 7.5 & 5.8 & $1.7^{* *}$ & 0.62 \\
\hline $\mathrm{OHV}$ riding & 8.1 & 6.7 & $1.4^{* *}$ & 0.49 & 7.6 & 6.2 & $1.4^{* *}$ & 0.42 \\
\hline Camping & 7.2 & 6 & $1.2 * *$ & 0.35 & 6.6 & 5.2 & $1.4^{* *}$ & 0.34 \\
\hline Hunting & 8.2 & 7.4 & $0.8 *$ & 0.17 & 8 & 7.5 & 0.5 & - \\
\hline Canoeing/kayaking & 7.2 & 5.6 & $1.6^{* *}$ & 0.59 & 6.7 & 5.3 & $1.4^{* *}$ & 0.49 \\
\hline
\end{tabular}

All activity users except campers and canoers/kayakers scored recreation satisfaction and scenic beauty the same for both good and poor-quality RCW habitats (Table 3). Campers, however, reported significantly lower recreation satisfaction than perceived scenic beauty in both habitat qualities $(p<0.05)$. Canoers/kayakers rated significantly lower attainment of recreation satisfaction than perceived scenic beauty in the good-quality habitat $(p<0.05)$, but their rating of recreation satisfaction was not statistically different from perceived scenic beauty in the poor-quality habitat. These results indicate a strong association between perception of scenic beauty and attainment of recreation satisfaction conditional upon activity of recreation participation and quality of RCW habitat.

Table 3. Comparison of perceived scenic beauty and recreation satisfaction from good and poor-quality red-cockaded woodpecker habitats in Ocala National Forest.

\begin{tabular}{|c|c|c|c|c|c|c|c|c|}
\hline \multirow[b]{2}{*}{ Recreation Activities } & \multicolumn{4}{|c|}{ Good Quality RCW Habitat } & \multicolumn{4}{|c|}{ Poor Quality RCW Habitat } \\
\hline & SB & RS & Diff. & $\begin{array}{l}\text { Effect } \\
\text { Size }\end{array}$ & SB & RS & Diff. & $\begin{array}{c}\text { Effect } \\
\text { Size }\end{array}$ \\
\hline Hiking/backpacking & 7.4 & 7.5 & 0.1 & - & 5.8 & 5.7 & 0.1 & - \\
\hline OHV riding & 8.1 & 7.6 & 0.5 & - & 6.7 & 6.2 & 0.5 & - \\
\hline Camping & 7.2 & 6.6 & $0.6^{*}$ & 0.14 & 6 & 5.2 & $0.8^{* *}$ & 0.18 \\
\hline Hunting & 8.2 & 8 & 0.2 & - & 7.4 & 7.5 & -0.1 & - \\
\hline Canoeing/kayaking & 7.2 & 6.7 & $0.4^{*}$ & 0.10 & 5.6 & 5.3 & 0.4 & - \\
\hline
\end{tabular}

\section{Discussion}

This research examined recreationists' responses to RCW habitat management by comparing ratings of scenic beauty and attainment of recreation satisfaction by activity of recreation participation and by quality of RCW habitat. Our findings offer important implications useful for the management of public forests to attain the dual goals of recreation and wildlife habitat management. They suggest that there are important differences in the perception of scenic beauty and satisfaction with recreational experience that differ depending on the nature of the recreational activity, pointing to the challenges 
managers face as they try to manage lands for multiple recreational uses. We also found that there were significant differences in how different recreation activity user groups perceive good and poor-quality RCW habitats and how it affected satisfaction with recreational experiences. This may further complicate the challenges for land managers who need to balance maintaining specific habitat conditions with the divergent perceptions of users of these lands.

Recreation users participating in various activities rated scenic beauty and recreation satisfaction differently, providing support for our first hypothesis (H1). Unlike the assumption in the SBE model [19], the results from this study indicate that recreation users have different standards for rating both scenic beauty and recreation satisfaction depending upon the activity in which they participate. This suggests that the public's acceptance of forest management treatments is culturally derived $[45,46]$ and that they do make judgments based on their immediate purpose in using the environment [36] and degree of connection to forest aesthetics when participating in the activity [30]. Forest managers therefore need to communicate effectively with the public regarding the ecological importance of active forest management treatments in order to make multi-objective forestry practices acceptable to a broad constituency.

Consistent with Brunson and Shelby [29], hikers and campers did not differ in terms of their perceptions of scenic beauty, but they did indicate significant differences in recreation satisfaction. Campers reported the lowest recreation satisfaction, regardless of the quality of the RCW habitat. Hunters, hikers/backpackers, and OHV users were likely to attain better recreation experiences than campers from forest sites being managed for RCW. This is likely because the former recreationists enjoy open, park-like conditions perpetuated by frequent low intensity fires that remove the hardwood midstory, whereas campers prefer dense hardwood midstories that provide visual shielding from other campers. Also, campers may have placed more importance on offsite attributes, such as whether water bodies or other recreation opportunity settings were visible in the pictures, than stand and site characteristics $[29,30]$. If so, promoting hiking/backpacking, hunting, and OHV riding opportunities in forests managed to promote RCWs (or areas requiring active management) and keeping camping sites away from these areas could result in positive outcomes. This would reduce the negative impacts of prescribed burning and some other management treatments on recreation users' attainment of expected experiences, be beneficial in minimizing conflict among land management objectives, and help managers achieve multiple objectives through forest management.

Most recreation activity user groups perceived higher scenic beauty and reported attainment of higher recreation satisfaction from good-quality habitats than from poor-quality RCW habitats, supporting our second hypothesis (H2). This finding indicates that forest sites maintained as good quality RCW habitats also offer quality recreation opportunities to visitors, a win-win scenario for multi-objective forestry practices. Expansion of forests that offer suitable RCW habitats is likely to not only benefit RCW populations and other dependent wildlife species (e.g., gopher tortoise), but also opens diverse opportunities for recreation users. The results also indicate that attainment of recreation satisfaction was strongly associated with the perception of scenic beauty in both good and poor-quality habitats for at least certain activity user groups, partially supporting our third hypothesis (H3). This finding indicates that maintaining scenery is fundamental to allowing visitors to attain satisfying experiences and to improving recreation users' understanding of the ecological importance of prescribed burning and other forest management treatments. However, the development of a good-quality RCW habitat is likely to have higher aesthetic and recreation value than a low-quality habitat. It will require several years and stages of active management (e.g., burning, thinning), which some recreation users may find less acceptable. Foresters will continue to confront the challenges of developing a forest site as a suitable RCW habitat while still providing satisfying recreation experiences. Development of an ecological perspective through a learning experience centered on the dynamic qualities of forest environments and the nature of both subtle and dramatic changes in the forest lifecycle [46] could encourage users to accept these treatments through a more inclusive perception of aesthetic quality. Improving recreationists' knowledge of active forest management for wildlife 
habitat improvement is important for achieving this goal. Most users of the Florida National Scenic Trail who pass through the ONF were either visiting to enjoy nature and scenery or visiting to obtain solitude. Recreation settings having quality nature, wilderness areas, and wildlife habitats were the most important site attraction attributes for these visitors. Thus, educational messages about prescribed burning should focus on how fire and other management treatments improve forest scenery over the long term, enhance habitat quality for wildlife, and sustain the overall health of the forest.

Finally, this study offers an important methodological implication regarding visual elicitation through the use of photographs to assess forest and landscape aesthetic perceptions and preferences. Like others, we used photographs to capture various forest conditions, but unlike most previous researchers, we obtained ratings of both scenic beauty and recreation satisfaction from onsite users. This elicitation method allowed respondents more time to reflect on their perspective of the actual sites as they rated them in the pictures. In addition, this time-efficient approach allowed researchers to be considerate of users' immediate purposes, such as hiking and camping, as they rated forest sites shown in the pictures. Previous research has often relied on respondents to remember or imagine a recreation visit. We believe this approach offers more valid and reliable assessment related to perception and preference of forest aesthetics.

\section{Limitations and Future Direction of Research}

We classified and compared respondents by activity of participation. While doing so, we classified respondents based on their first major activity at the time of data collection [47]. However, the activities people choose to pursue are not necessarily mutually exclusive. Users can participate in more than one equally important activity in a single visit or at a single site in a forest $[30,47]$. When asked to report three activities in order of importance, about $10 \%$ of respondents, such as those who hiked and camped, struggled to select one activity as more important than the other. This generates the potential for some inaccuracies or poor precision in the classification of respondents by activity. Some alternative approaches would be to classify respondents into "appreciative", "consumptive", and "motorized" activities based on their reported most important activities [47] or based on their frequency of participation in various recreation activities over a period of 12 months [48]. However, these approaches would have compromised the distinction we have observed between hikers and campers, who would fall into the same category in these approaches and would also fail to capture the immediate purpose of respondents in evaluating the forest scenery, which was one of the major focuses of this study. Future research should consider adopting more effective classification criteria that could generate more definitive conclusions about the relationships between people's recreational activities and their perceptions of scenic beauty and recreation satisfaction.

We used a single picture to represent each forest site condition considered in this study. A single photograph cannot represent the diversity of a surrounding environment seen from a specific viewpoint [49]. Thus, the reliability and validity of such assessments could be improved by using panoramic photographs or forest walk simulations using $360^{\circ}$ cameras. In addition, we used photographic images representing different times after burning across different forest sites rather than for a single site. Tracking the same sites before and after burning and other management treatments for multiple years (time lapse photos) and assessing recreation users' perceptions of scenic beauty and recreation satisfaction in a longitudinal research design will offer more robust evidence to confirm or disconfirm the findings presented in this study.

\section{Conclusions}

This study confirms that forest aesthetic perception and preference depend upon an individual's immediate purpose in using an environment. In other words, the recreation activity users choose affects their evaluation of forest management treatments in terms of aesthetic and recreational quality. Future studies should consider users' purpose for visiting a site in any assessment of aesthetic preferences and visit experiences. Scenery management programs in public forest should maintain 
the activities that a targeted site provides for users. For example, keeping camping sites away from RCW habitats or areas requiring active management will provide these users with a more positive outcome. On the other hand, such sites are appropriate for hunters, hikers/backpackers, and $\mathrm{OHV}$ users. Research related to wildlife habitat management has shown that forest sites developed as good-quality RCW habitats also offer habitats for many other wildlife species, including the gopher tortoise. This research indicates that a good-quality RCW habitat also offers higher scenic and recreational quality. Expansion of RCW habitat can not only support the recovery of this endangered species and benefit many other wildlife species, but it can also offer quality recreation opportunities for visitors. Nonetheless, improving recreationists' ecological knowledge remains important in order to improve users' experience when they recreate in forest sites under development as RCW habitats with the requisite frequent and intensive application of treatments, particularly prescribed burning. Hunters rated higher scenic beauty and recreation satisfaction of forest sites representing various forms of active management than other activity users, suggesting that developing programs to facilitate knowledge transfer from hunters to other recreation users could be beneficial.

Supplementary Materials: The following are available online at http:/ /www.mdpi.com/1999-4907/9/5/241/s1, Figure S1: Photographic images used for panel selection of good and poor-quality RCW habitat in Ocala National Forest, USA.

Author Contributions: R.P., T.V.S., H.K.O., and E.J.J. developed conceptual ideas; R.P. designed the study, conducted data collection and analysis, and wrote the paper; T.V.S., M.E.S., and D.C.A. contributed to the design and study instrument; T.V.S., H.K.O., M.E.S., and E.J.J. edited the manuscript.

Funding: This research received no external funding.

Acknowledgments: This research was supported by the funding from a cooperative agreement between University of Florida and the USDA Forest Service National Forests in Florida. Authors would like to acknowledge Carson Young for his assistance in data collection and panel reviewers for their help in selection of pictures representing good quality and poor-quality RCW habitats. We also thank two anonymous reviewers for their valuable suggestions.

Conflicts of Interest: The authors declare no conflict of interest.

\section{References}

1. US Fish and Wildlife Service. Red-Cockaded Woodpecker Recovery. Available online: http://www.fws. gov/rcwrecovery/rcw.html (accessed on 26 August 2015).

2. Walters, J.R.; Doerr, P.D.; Carter, J. The cooperative breeding system of the red-cockaded woodpecker. Ethology 1988, 78, 275-305. [CrossRef]

3. Conner, R.N.; O'Halloran, K.A. Cavity-tree selection by red-cockaded woodpeckers as related to growth dynamics of southern pines. Wilson Bull. 1987, 99, 398-412.

4. US Fish and Wildlife Service. Recovery Plan for the Red-Cockaded Woodpecker (Picoides Borealis): Second Revision; US Fish and Wildlife Service: Atlanta, GA, USA, 2003.

5. Rudolph, D.C.; Conner, R.N.; Schaefer, R.R. Red-cockaded woodpecker foraging behavior in relation to midstory vegetation. Wilson Bull. 2002, 114, 235-242. [CrossRef]

6. Platt, W.J.; Evans, G.W.; Davis, M.M. Effects of fire season on flowering of forbs and shrubs in longleaf pine forests. Oecologia 1988, 76, 353-363. [CrossRef] [PubMed]

7. Provencher, L.; Herring, B.J.; Gordon, D.R.; Rodgers, H.L.; Tanner, G.W.; Hardesty, J.L.; Brennan, L.A.; Litt, A.R. Longleaf pine and oak responses to hardwood reduction techniques in fire-suppressed sandhills in northwest florida. For. Ecol. Manag. 2001, 148, 63-77. [CrossRef]

8. Brown, T.C.; Daniel, T.C. Predicting scenic beauty of timber stands. For. Sci. 1986, 32, 471-487.

9. Haider, W. The aesthetics of white pine and red pine forests. For. Chron. 1994, 70, 402-410. [CrossRef]

10. Haider, W.; Hunt, L. Visual aesthetic quality of northern ontario's forested shorelines. Environ. Manag. 2002, 29, 324-334. [CrossRef]

11. Ramirez, E.M.; Ober, H.K. Nest site selection and reproductive success of red-cockaded woodpeckers in ocala national forest. Am. Midl. Nat. 2014, 171, 258-270. [CrossRef]

12. Gobster, P.H. An ecological aesthetic for forest landscape management. Landsc. J. 1999, 18, 54-64. [CrossRef] 
13. Ribe, R.G. Regeneration Harvests versus Clearcuts: Public Views of the Acceptability and Aesthetics of Northwest Forest Plan Harvests. Northwest Sci. 1999, 73, 102-117.

14. USDA Forest Service. Landscape Aesthetics: A Handbook for Scenery Management; Agriculture Handbook Number 701; USDA Forest Service: Washington, DC, USA, 1995.

15. Williams, K.; Cary, J. Landscape preferences, ecological quality, and biodiversity protection. Environ. Behav. 2002, 34, 257-274. [CrossRef]

16. Ryan, R.L. Social Science to Improve Fuels Management: A Synthesis of Research on Aesthetics and Fuels Management; Gen. Tech. Rep. NC-261; U.S. Department of Agriculture, Forest Service, North Central Research Station: St. Paul, MN, USA, 2005; p. 58.

17. Anderson, L.M.; Levi, D.J.; Daniel, T.C.; Dieterich, J.H. The Esthetic Effects of Prescribed Burning: A Case Study; Research paper rm-415; USDA Forest Service, Rocky Mountain Forest and Range Experiment Station: Fort Collins, CO, USA, 1982.

18. Conner, R.N.; Rudolph, D.C.; Schaefer, R.R.; Saenz, D. Long-distance dispersal of red-cockaded woodpeckers in texas. Wilson Bull. 1997, 109, 157-160.

19. Daniel, T.C.; Boster, R.S. Measuring Landscape Esthetics: The Scenic Beauty Estimation Method; USDA Forest Service Research Paper RM-167; Rocky Mountain Forest and Range Experiment Station: Fort Collins, CO, USA, 1976.

20. Daniel, T.C.; Vining, J. Methodological issues in the assessment of landscape quality. In Human Behavior and Environment; Altman, I., Wohlwill, J., Eds.; Plenum Press: New York, NY, USA, 1983; Volume 6, pp. $39-84$.

21. Daniel, T.C. Whither scenic beauty? Visual landscape quality assessment in the 21st century. Landsc. Urban Plan. 2001, 54, 267-281. [CrossRef]

22. Johnson, R.L.; Brunson, M.W.; Kimura, T. Using image-capture technology to assess scenic value at the urban/forest interface: A case study. J. Environ. Manag. 1994, 40, 183-195. [CrossRef]

23. Moore, R.L.; Driver, B. Introduction to outdoor recreation: Providing and managing natural resource based opportunities. J. Park Recreat. Adm. 2005, 25, 113-115.

24. Manning, R.E. Studies in Outdoor Recreation: Search and Research for Satisfaction; Oregon State University Press: Corvallis, OR, USA, 1999.

25. Bultena, G.L.; Klessig, L.L. Satisfaction in camping: A conceptualization and guide to social research. J. Leis. Res. 1969, 1, 348-354. [CrossRef]

26. Graefe, A.R.; Burns, R.C. Testing a mediation model of customer service and satisfaction in outdoor recreation. J. Outdoor Recreat. Tour. 2013, 3, 36-46. [CrossRef]

27. Sevenant, M.; Antrop, M. Cognitive attributes and aesthetic preferences in assessment and differentiation of landscapes. J. Environ. Manag. 2009, 90, 2889-2899. [CrossRef] [PubMed]

28. Tahvanainen, L.; Tyrväinen, L.; Ihalainen, M.; Vuorela, N.; Kolehmainen, O. Forest management and public perceptions-Visual versus verbal information. Landsc. Urban Plan. 2001, 53, 53-70. [CrossRef]

29. Brunson, M.W.; Shelby, B. Assessing recreational and scenic quality: How does "new forestry" rate? J. For. 1992, 90, 37-41.

30. Berns, G.N.; Simpson, S. Outdoor recreation participation and environmental concern: A research summary. J. Exp. Educ. 2009, 32, 79-91.

31. Buhyoff, G.J.; Leuschner, W.A. Estimating psychological disutility from damaged forest stands. For. Sci. 1978, 24, 424-432.

32. Ruddell, E.J.; Gramann, J.H.; Rudis, V.A.; Westphal, J.M. The psychological utility of visual penetration in near-view forest scenic-beauty models. Environ. Behav. 1989, 21, 393-412. [CrossRef]

33. Kearney, A.R.; Bradley, G.A. The effects of viewer attributes on preference for forest scenes: Contributions of attitudes, knowledge, demographic factors, and stakeholder group membership. Environ. Behav. 2011, 43, 147-181. [CrossRef]

34. Edwards, D.; Jay, M.; Jensen, F.S.; Lucas, B.; Marzano, M.; Montagné, C.; Peace, A.; Weiss, G. Public preferences for structural attributes of forests: Towards a pan-european perspective. For. Policy Econ. 2012, 19, 12-19. [CrossRef]

35. Zube, E.H.; Sell, J.L.; Taylor, J.G. Landscape perception: Research, application and theory. Lands. Plan. 1982, 9, 1-33. [CrossRef]

36. Hull, R.B.; Reveli, G.R. Cross-cultural comparison of landscape scenic beauty evaluations: A case study in bali. J. Environ. Psychol. 1989, 9, 177-191. [CrossRef] 
37. Frank, S.; Fürst, C.; Koschke, L.; Witt, A.; Makeschin, F. Assessment of landscape aesthetics_-Validation of a landscape metrics-based assessment by visual estimation of the scenic beauty. Ecol. Indic. 2013, 32, 222-231. [CrossRef]

38. Kearney, A.R. Effects of an informational intervention on public reactions to clear-cutting. Soc. Nat. Resour. 2001, 14, 777-790. [CrossRef]

39. Lim, S.H.; Bowker, J.M.; Johnson, C.Y.; Cordell, H.K. Perspectives on prescribed fire in the south: Does ethnicity matter? South. J. Appl. For. 2009, 33, 17-24.

40. Fix, P.J.; Carroll, J.; Harrington, A.M. Visitor experiences across recreation settings: A management or measurement issue? J. Outdoor Recreat. Tour. 2013, 3, 28-35. [CrossRef]

41. USDA Forest Service. National Forest Visitor Use Monitoring Training Manual; National Visitor Use Monitoring Program: Washington, DC, USA, 2013.

42. Kreimer, A. Environmental preferences: A critical analysis of some research methodologies. J. Leis. Res. 1977, 9, 88-97. [CrossRef]

43. Hamby, T.; Taylor, W. Survey satisficing inflates reliability and validity measures: An experimental comparison of college and amazon mechanical turk samples. Educ. Psychol. Meas. 2016, 76, 912-932. [CrossRef]

44. Cohen, J. Statistical Power for the Behavioral Sciences, 2nd ed.; Lawrence Erlbaum Associates: Hillsdale, NJ, USA, 1988.

45. Gobster, P.H. Aldo leopold's ecological esthetic: Integrating esthetic and biodiversity values. J. For. 1995, 93, 6-10.

46. Gobster, P.H. The Aesthetic Experience of Sustainable Forest Ecosystems. In Sustainable Ecological Systems: Implementing an Ecological Approach to Land Management; Covington, W., DeBanco, L.F., Eds.; General Technical Report RM-247; USDA Forest Service, Rocky Mountain Forest and Range Experiment Station: Fort Collins, CO, USA, 1994; pp. 246-255.

47. Thapa, B.; Graefe, A.R. Forest recreationists and environmentalism. J. Park Recreat. Adm. 2003, 21, 75-103.

48. Tarrant, M.A.; Green, G.T. Outdoor recreation and the predictive validity of environmental attitudes. Leis. Sci. 1999, 21, 17-30.

49. Palmer, J.F.; Hoffman, R.E. Rating reliability and representation validity in scenic landscape assessments. Landsc. Urban Plan. 2001, 54, 149-161. [CrossRef] 